[Agr. Biol. Chem., Vol. 30, No. 7, p. 667 673, 1966]

\title{
Role of Phenylalanine Deaminase and Tyrase in the Lignification of Bamboo
}

\author{
By Takayoshi HrguchI \\ Laboratory of Wood Chemistry, Faculty of Agriculture, \\ Gifu University, Kakamigahara, Gifu \\ Received January 27, 1966
}

\begin{abstract}
A pronounced increase of the activity of phenylalanine deaminase and tyrase during the lignification of bamboo shoots was observed. With progressing maturation from the basal part to the upper part of immature bamboos the pattern of the activity of the enzymes moved toward the upper part of the tissues, where the most active lignification was taking place, and the amount of cinnamic acid derivatives in the tissues was found to be in good accordance with the activity of the enzymes. L-Phenylalanine-G- ${ }^{14} \mathrm{C}$ and $\mathrm{L}$-tyrosine- $\mathrm{G}-{ }^{14} \mathrm{C}$ were both well incorporated into the lignin of bamboos. These results indicate that phenylalanine deaminase and tyrase are synthesized progressively just before the lignification of the bamboos and by the enzymes L-phenylalanine and L-tyrosine are deaminated to cinnamic acid derivatives and incorporated into lignin.
\end{abstract}

Since the finding of phenylalanine deaminase (phenylalanine ammonia-lyase) and tyrase (tyrosine ammonia-lyase) by Koukol and Conn, ${ }^{1)}$ and Neish, ${ }^{2}$ respectively, several papers on the possible role of the emzymes in phenol metabolism have been reported. Yoshida and Shimokoriyama ${ }^{3}$ found that phenylalanine deaminase activity develops in parallel with the lignification in stems of a buckwheat plant. Minamikawa and Uritani ${ }^{4 \sim 6)}$ showed that both phenylalanine deaminase and tyrase increase markedly in sweet potato root in response to wounding or infection by a certain pathogenic fungus and the increase of the enzymes are closely related to the biosynthesis of polyphenols in the tissues.

1) J. Koukol and E.E. Conn, J. Biol. Chem., 236, 2692 (1961).

2) A.C. Neish, Phytochem., I, 1 (1961).

3) S. Yoshida and M. Shimokoriyama, Bot. Mag. (Tokyo), 78,14 (1965).

4) T. Minamikawa and I. Uritani, Arch. Biochem. Biophys., 108, 573 (1964).

5) T. Minamikawa and I. Uritani, J. Biochem., 57, 678 (1965).

6) T. Minamikawa and I. Uritani, This Journal, 29, 1021 (1965).
Zucker ${ }^{7 /}$ also indicated an inductive synthesis of phenylalanine deaminase in culture of the sliced potato tuber, and that the activity of the enzyme is proportional to the initial rate of chlorogenic acid synthesis in the tissue.

In the authers previous papers ${ }^{8 \sim 9)}$ it was established that phenylalnine deaminase is found in several tissues cultured in vitro and in the cambial tissues of young stems of many conifers and broadleaved trees, and that the enzyme should be responsible for the lignification of those tissues.

The present paper provides evidence that phenylalanine deaminase and tyrase are both synthesized progressively during the lignification of bamboo shoots and the enzymes participate in the lignification of the bamboo.

\section{MATERIALS AND METHODS}

\section{Samples}

Bamboo shoots (length, 0.14 to $1.20 \mathrm{~m}$ ) and the

7) M. Zucker, Plant physiol., 40, 779 (1965).

8) T. Higuchi and F. Barnoud, Symp. Intern. Chimie, Biochimie, Lignine, Cellulose, Hemicelluloses. p. 255 (1964).

9) T. Higuchi and F. Barnoud, J. Jap. Wood Res. Soc., 12, 36 (1966). 
stems of immature bamboo (length, 4.0 to $8.8 \mathrm{~m}$ ) of Mōso (Phyllostachys pubescens) and Madake (Phyllostachys reticulata) were collected from the Experimental Farm of Gifu University. They were cut into several portions in proportion to the length and to the lignification degree of the samples. The sheath was peeled off and $20 \mathrm{~g}$ of the tissue in each portion was cut into small pieces.

\section{Extraction of Phenylalanine Deaminage and Tyrase}

Following the procedure of Koukol and Conn, 1) the enzymes were extracted from the acetone powder which was prepared from $20 \mathrm{~g}$ of small pieces of the tissues of bamboo shoots or immature bamboo stems.

The tissue was ground in a high speed homogenizer with $200 \mathrm{ml}$ of cold acetone $\left(-18^{\circ} \mathrm{C}\right)$, and the homogenate was filtered by suction. The residue was washed with cold acetone twice and spread to dry on a filter paper in a draft chamber. The dry fibrous powder was extracted for 1 hour with cold $0.1 \mathrm{M}$ borate buffer $(\mathrm{pH} 8.8)$ in a refrigerator. The extract was sequeezed through cheese cloth and clarified by centrifugation. Solid ammonium sulfate was added into the extract little by little with stirring to $70 \%$ saturation at $3^{\circ} \mathrm{C}$. The precipitated enzyme was collected by centrifugation and dissolved in a small amount of the same buffer and dialized against $0.05 \mathrm{M}$ borate buffer ( $\mathrm{pH}$ 8.8). The dialized enzyme solution contained both phenylalanine deaminase and tyrase.

\section{Standard Assay of the Enzymes}

Two $\mathrm{ml}$ of $0.1 \% \mathrm{~L}$-phenylalanine or L-tyrosine in $0.1 \mathrm{M}$ borate buffer ( $\mathrm{pH} 8.8), 1 \mathrm{ml}$ of enzyme solution and $2 \mathrm{ml}$ of distilled water were added in a test tube, and the reaction mixture was shaken for 3 hours at $30^{\circ} \mathrm{C}$ in a Taiyo incubator type $\mathrm{M} 1$. The reaction was stopped by adding $0.4 \mathrm{ml}$ of $3 \mathrm{~N}$ hydrochloric acid and the reaction mixture was extracted twice with each $5 \mathrm{ml}$ of ether, and ether was evaporated under air stream. The residue was dissolved in a suitable amount of $0.05 \mathrm{~N}$ sodium hydroxide, and the optical density of the solutions at $268 \mathrm{~m} \mu$ (for trans-cinnamic acid) or $333 \mathrm{~m} \mu$ (for trans-p-coumaric acid) was measured. The amount of trans-cinnamic acid or trans-p-coumaric acid formed was calculated from the molar extinction coefficient of the respective acids. No formation of the acids occurred when boiled enzymes were used as well as the enzymes or substrates were omitted from the reactions. The unit of the activity was defined as the amount of enzyme catalyzing the formation of $1 \mu \mathrm{g}$ of transcinnamic or $p$-coumaric acid per hour under standard assay condition.

\section{Determination and Isolation of Phenolic Acids}

Respective portions of a immature bamboo stem of Mōso were homogenized in hot ethanol, the homogenate was filtered, and the residue was washed with hot $80 \%$ ethanol. The filtrate and washings were combined, concentrated almost to dryness in a rotatory evaporator, and the residue was dissolved in a suitable amount of hot water and filtered. The water-soluble fraction thus obtained was acidified and continuously extracted for 10 hours with ether. The ether-soluble fraction was separated into acidand acid-free fractions by extraction of the ether solution with $5 \%$ sodium bicarbonate, and after acidification of the bicarbonate solution the acid fraction was re-extracted with either. The etherial acid solution was divided into two parts of the same volume and one part was used for the determination, and the other part was used for the identification and isolation of phenolis acids. For determinaton, ether was evaporated and the residue was dissolved in a suitable amount of $0.05 \mathrm{~N}$ sodium hydroxide and the amount of trans-cinnamic and p-coumaric acids were determined spectrophotometrically as described above. For identification the ether extract was subjected to paper chromatography in $1 \%$ acetic acid $(\mathrm{v} / \mathrm{v})$ and in the organic layer of toluene-acetic acid-water $(4: 1: 5$, $v / v)$, respectively. The spots of phenolic acids were detected with the aid of a diazotized $p$-nitroaniline spray or ultraviolet light. The corresponding spots of $p$-coumaric and ferulic acids on the chromatogram irrigated with toulene-acetic acid-water were extracted with hot acetone, ${ }^{10}$ ) and the acids thus obtained were further purified successively by paper chromatography in the organic layer of $n$-butanol-0.8 M ammonium carbonate- $1.5 \mathrm{~N}$ ammonium hydroxide $(2: 1: 1, \mathrm{v} / \mathrm{v})$. The purified acids were dissolved in a suitable amount of $0.05 \mathrm{~N}$ sodium hydroxide and their ultraviolet spectra were measured by a Hitachi-Perkin Elmer $139 \mathrm{UV}$ VIS spectrophotometer.

\section{Lignin Determination}

The cell wall residue of acetone powder which the enzymes had been extracted was extracted with ethanol-benzene $(1: 1, \mathrm{v} / \mathrm{v})$ for 10 hours and hot water for 4 hours, successively and lignin was determined by Klason methd.

10) T. Higuchi and S. A. Brown, Can. J. Biochem. Physiol., 41, 621 (1963). 


\section{Nitrobenzene Oxidation}

The extractive-free cell wall residue prepared previously was subjected into alkaline nitrobenzene oxidation. Cell wall residue $(1 \mathrm{~g}), 8 \%$ sodium hydroxide solution $(10 \mathrm{ml})$ and nitrobenzene $(1 \mathrm{ml})$ were added in a small stainless tube vessel and oxidized at $160^{\circ} \mathrm{C}$ for 3 hours. The reaction mixtures were filtered and washed with ether. The washed alkaline solution was acidified to $\mathrm{pH} 3$ with hydrochloric acid and the lignin degradation products were extracted with ether. Ether was evaporated and the residues were dissolved in $1 \mathrm{ml}$ of acetone and analyzed by gas-liquid chromatography using a column of Apiezone $\mathrm{N}$ on Fluoropack. ${ }^{11}$ )

Administration of Labeled L-Phenylalanine and L-Tyrosine

L-Phenylalanine-G-14C and L-tyrosine-G-14C were purchased from the Radiochemical Center Amersham, Buckinghamshire, England. The labeled compounds $(5 \mu \mathrm{C})$ were administered as aqueous solutions through the cut ends of the young branches about $40 \mathrm{~cm}$ in length of Mōso and Madake and the plants were allowed to metabolize 24 hours in the light.

\section{Ethanolysis of the Fed Plants}

The fed plants were cut into about $1 \mathrm{~cm}$ pieces and extracted with boiled $80 \%$ ethanol. The extracted plant materials were dried and pulverized. The powder thus obtained was extracted with ethanolbenzene $(1: 1, v / v)$ and hot water, successively. The extracted powder was subjected into ethanolysis. Cell wall residue $(10 \mathrm{~g})$ and $150 \mathrm{ml}$ of ethanol containing $3 \%$ hydrogen chloride were added in an Elrenmeyer flask and refluxed for 48 hours. The reaction mixtures were filtered and concentrated into a small volume (about $15 \mathrm{ml}$ ) and the concentrated ethanol solution was added dropwise into $100 \mathrm{ml}$ of water to precipitate lignin. The lignin was filtered and dissolved in a small amount of ethanol and treated again in the same way. The filtrates in both cases were combined, concentrated and extracted with ether for 48 hours. The ethanolysis oil thus extracted was oxidized to diketones with ferric chloride in ethanol, and the ferric chloride was removed as ferric hydroxide with ammonia. The diketones produced were re-extracted with ether, and after evaporation of ether, the mixtures of diketones were dissolved in hot water and they were converted into their nickel glyoxime salts by refluxing with hydroxylamine

11) J.M. Pepper, M. Manolopoulo, and R. Burton, Can.J. Chem., 40, 1976 (1962). hydrochloride and nickel chloride in the presence of sodium acetate. The glyoxime salts obtained were hydrolysed with sulfuric acid and the free diketones were extracted with ether. Vanilloyl acetyl and syringoyl acetyl in the extract were isolated and purified by paper chromatography in the organic layer of ligroin-chloroform-methanol-water $(7: 2: 1: 5$, $\mathrm{v} / \mathrm{v})$ as a solvent and the extracted diketones from the chromatogram were further purified by a small column $(6 \mathrm{~mm} \times 60 \mathrm{~mm})$ of silicic acid (Mallinckrodt Chemical Works) using isopropyl ether saturated with water. ${ }^{12}$ \}

\section{Measurement of Radioactivity}

The radioactivity of the compounds was measured by a gas flow counter Tracerlab.

\section{RESULTS AND DISCUSSION}

Distributions of Phenylalanine Deaminase and Tyrase in Bamboo Shoots

The ultraviolet absorption spectrum and

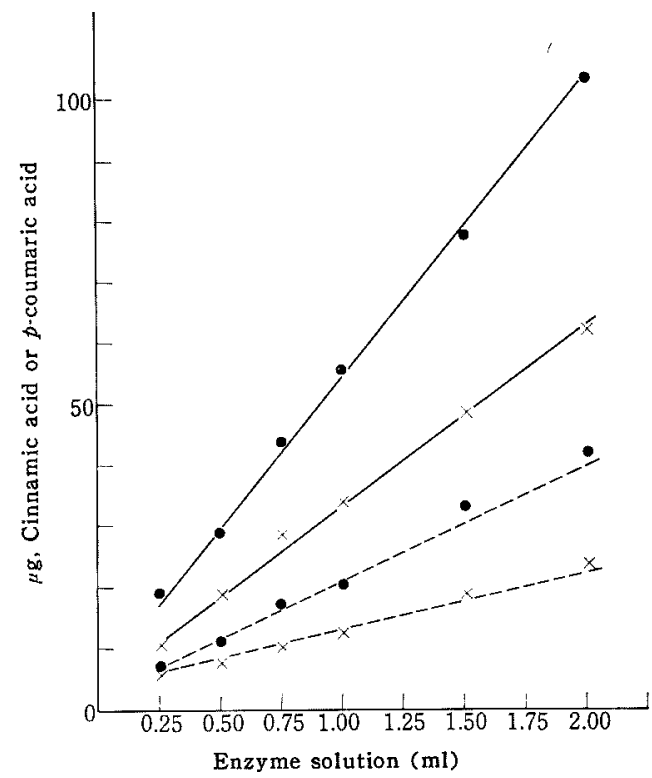

FIG. 1. Effect of Enzyme Concentration on the Rate of Reaction.

Enzymes from the basal part of bamboo shoot (length, $0.36 \mathrm{~m}$ ) of $P$. pubescens.

$x$ Enzymes from the upper part of the same bamboo shoot. Cinnamic acid

$p$-Coumaric acid

12) T. Higuchi and I. Kawamura, Holzforsch., 20, 16 (1966). 
$R_{F}$ value of the products by phenylalanine deaminase and tyrase were compared with those of authentic trans-cinnamic and trans-pcoumaric acids, respectively, and these were completely identical with those of the respective acids. ${ }^{2,9}$

Fig. 1 shows that the formation of cinnamic and $p$-coumaric acids completely depend on the amount of enzyme solution used.

Typical examples of the activity of phenylalanine deaminase and tyrase of different portions of the bamboo shoots of Môso (length, $0.90 \mathrm{~m}$ ) and Madake (length, $1.0 \mathrm{~m}$ ) are shown in Figs. 2 and 3, respectively. In both bamboo shoots the activity of the enzymes was proportional to the maturation degree of the plants and the activity was highest in the basal portion, rapidly decreasing toward the upper portion of the shoots.

The activity of tyrase was about one third of that of phenylalanine deaminase and the pattern of the enzyme activity was similar to

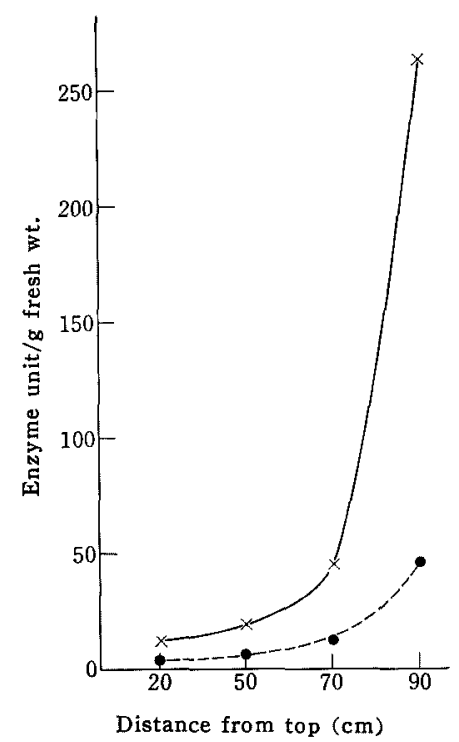

FIG. 2. Activity of Phenyl Alanine Deaminase and Tyrase of Different Portions of Bamboo Shoot (length, $0.90 \mathrm{~m}$ ) of $P$. pubescens.

$\times$ Phenyl alanine deaminase.

- Tyrase.

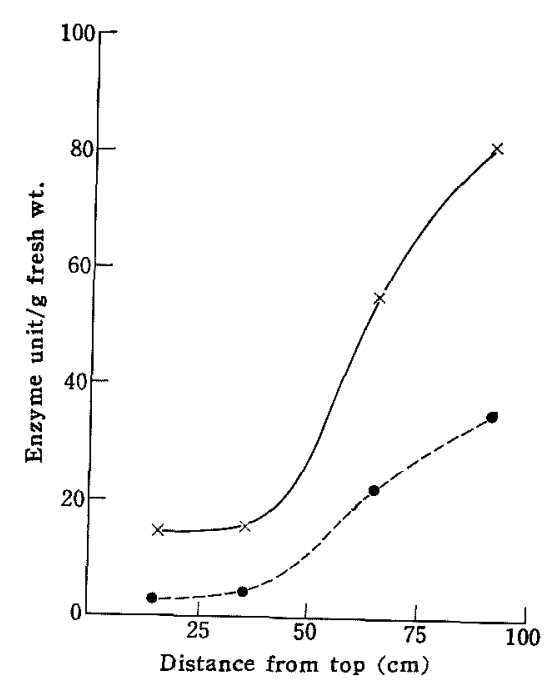

FIG. 3. Activity of Phenyl Alanine Deaminase and Tyrase of Different Portions of Bamboo Shoot (length, $1.0 \mathrm{~m}$ ) of $P$. reticulata.

$\times$ Phenyl alanine deaminase.

that of phenylalanine deaminase in both species of bamboo shoot.

The upper part of the bamboo shoots gave weak positive reactions for phloroglucinolhydrochloric acid and Mäule reagent in only spiral vessels of the apex and then the reactions extended around the other types of vessels and sieve tubes in lower portions. In the middle and basal portions the reactions became stronger in the vessels and sieve tubes but the reactions were still negative in the surrounding parenchyma tissues.

Distributions of Phenylalanine Deaminase, Tyrase, Cinnamic acids and Lignin in Immature Bamboo

In further experiments young immature bamboo stems of Mōso (length, $4.0 \mathrm{~m}$ ) were cut into 7 portions and the activity of the enzymes in the respective portions were compared. The results are shown in Fig. 4. The activity of phenylalanine deaminase and tyrase increased progressively from the top of the stem to lower portions, but at the basal portion, where the tissue was quite hard, the 


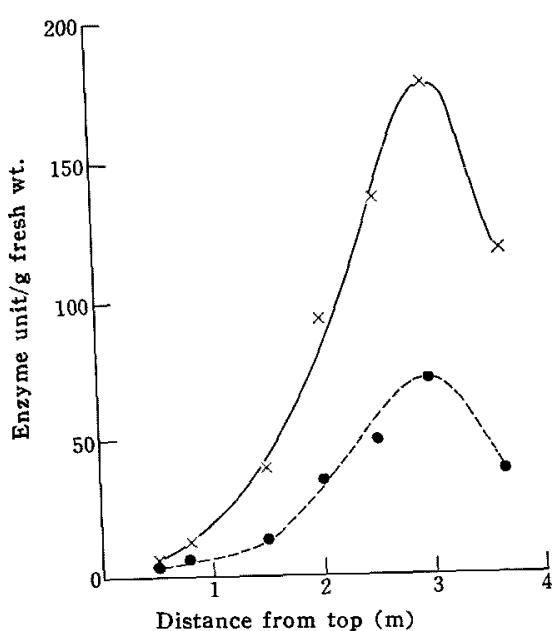

FIG. 4. Activity of Phenyl Alanine Deaminase and Tyrase of Different Portions of Immature Bamboo Stem (length, $4.0 \mathrm{~m}$ ) of $P$. pubescens.

$\times$ Phenyl alanine deaminase.

- Tyrase.

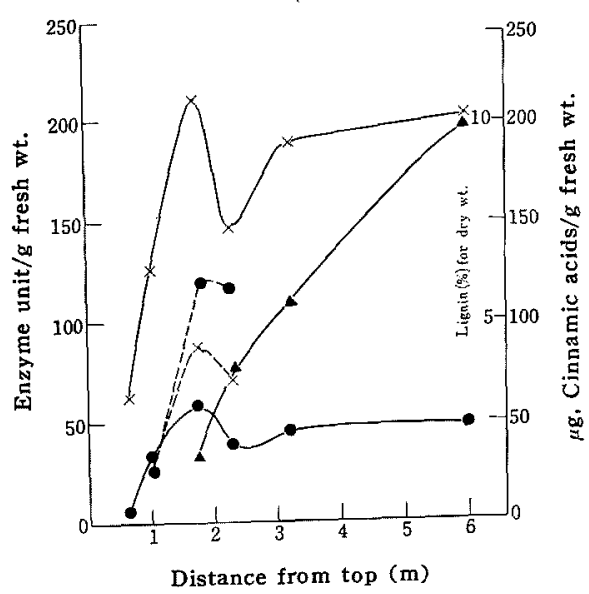

FIG. 5. Activity of Enymes and Amount of Cinnamic Acids and Lignin of Different Portions of Immature Bamboo Stem (length, $8.8 \mathrm{~m}$ ) of $P$. pubescens.

$$
\begin{aligned}
& \text {-x- Phenyl alanine deaminase. } \\
& - \text { Tyrase. } \\
& -x-\text { Cinnamic acid. } \\
& \text { - p-Coumaric acid. } \\
& \text { - Lignin. }
\end{aligned}
$$

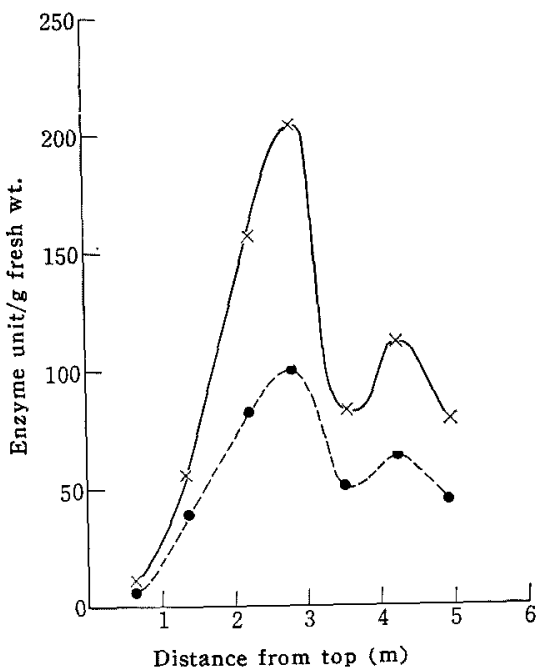

Fig. 6. Activity of Phenyl Alanine Deaminase and Tyrase of Different Portion of Immature Bamboo Stem (length, $6.6 \mathrm{~m}$ ) of $P$. reticulata.

$\times$ Phenyl alanine deaminase.
Tyrase.

vessels gave strong lignin reactions and the parenchyma tissues also gave weak reactions, the enzyme activity decreased.

Figs. 5 and 6 show the movement of the localisation of the activity of phenylalanine deaminase and tyrase as well as the pattern of the amount of cinnamic acids and lignin depening on the progressing maturation from the basal part to the upper part of immature bamboo stems.

In the youngest shoot the activity increased from the top to the basal portion progressively, whereas the enzyme activity of the more matured bamboo stem (length, $4.0 \mathrm{~m}$ ) increased progressively from the top to lower portions but at the basal portion where the lignification began in the parenchyma tissue the activity decreased. In the most matured bamboo (length, $8.8 \mathrm{~m}$, branches are beginning to develop and lower two third of the stem is quite hard and lignified) the activity increased from the top to the adjacent portions but the activity decreased at the part of one third of 
the stem length where the tissue is quite hard and parenchyma is lignified. In other words, the pattern of the enzyme activity moves toward the upper part of the tissue, where the lignification is taking place most actively, during maturation of bamboo.

The pattern of the amount of cinnamic acids in the respective portions was found to be in good accordance with that of the activity of the enzymes, and $p$-coumaric and ferulic acids were identified by paper chromatography and by ultraviolet absorption spectrum. ${ }^{101}$ The amount of lignin gradually increased with maturation of the bamboo and the increase of lignin was likely parallel with that of the enzyme activity.

These results are consistent with a previous work $^{13)}$ which showed the synthesis of phenylalanine deaminase and tyrase during germination of corn. There was no enzyme in the corn seed but in germination both enzyme were formed rapidly and followed by the formation of ether-soluble phenolic compounds, which were mainly consist of cinnamic acids, and lignin successively.

Phenylalanine deaminase and tyrase are both key enzymes in the synthesis of phenolic compounds because these enzymes irreversibly divert the phenylalanine and tyrosine in the protein metabolism into the synthesis of phenolic compounds. In young meristematic tissues the protein metabolism is active but in the cesation of cell division cell wall synthesis takes place with cell growth. In the cell wall synthesis polysaccharides formation precedes and after the completion of the synthesis lignification begins at the corner of primary cell wall. ${ }^{14)}$ During this stage phenylalanine deaminase and tyrase should be formed increasingly and the phenylalanine and tyrosine which have been incorporated into protein begins to deaminate to cinnamic acids as precursor of phenolic compounds

13) F. Lefevre, Thése Doctorat, $3^{e}$ cycle. Université de Grenoble, France (1964).

14) A.B. Wardrop and D.E. Bland, Proc. 4th Intern. Congr. Biochem., II, 92 (1958).
Table I. Molecular Ratio of ARomatic AldeHYDES FROM LIGNIN IN NITROBENZENE OXIDATION OF AN IMMATURE BAMBOO STEM OF P. pubescens

The part sample taken (Distance from top) (m)

2

3

4

7

8

$\begin{array}{ccc}\text { Vanillin } & \begin{array}{c}\text { Syring- } \\ \text { aldehyde }\end{array} & \begin{array}{c}p \text {-Hydroxy- } \\ \text { benzaldehyde }\end{array} \\ 1 & 0.51 & 1.40 \\ 1 & 0.62 & 1.10 \\ 1 & 0.67 & 0.95 \\ 1 & 0.73 & 0.90 \\ 1 & 0.77 & 0.91\end{array}$

including lignin.

In Table I the ratio of aromatic aldehydes in the alkaline nitrobenzene oxidation of the respective portions of the immature bamboo stem (length, $8.8 \mathrm{~m}$ ) of Mōso is given. The results are consistent with an earlier work ${ }^{15)}$ which showed that $p$-hydroxybenzaldehyde is predominant and the amount of vanillin and syringaldehyde is quite low in the upper portion, whereas in the lower portions the amount of vanillin and syringaldehyde increases in comparison to the amount of $p$ hydroxybenzaldehyde and that in the most matured tissue syringaldehyde is predominant.

In a separate experiment, ${ }^{16)}$ the present author found that a considerable part of $p$ hydroxybenzaldehyde formed in the alkaline nitrobenzene oxidation of grasses is originated from the p-coumaric acid connected with lignin by an ester linkage. Considering that the activity of tyrase is very strong in grasses as compared to that in dicotylendones the $p$ coumaric acid connected with lignin should be formed by the catalysis of tyrase.

Incorporation of L-Phenylalanine-G-14C and $\mathrm{L}$ Tyrosine-G-14C into Lignin

The results of the incorporation of $\mathrm{L}$-phenylalanine- $\mathrm{G}-{ }^{14} \mathrm{C}$ and $\mathrm{L}$-tyrosine- $\mathrm{G}-{ }^{14} \mathrm{C}$ into the lignins of Mōso and Madake are shown in Table II. The incorporation of both com-

15) T. Higuchi, I. Kawamura, I. Morimoto and T. Kanda, J. Jap. Forest. Soc., 36, 101 (1954).

16) T. Higuchi and I. Kawamura, Unpublished work. 
pounds into vanilloyl acetyl and syringoyl acetyl obtained in the ethanolysis of the fed

TABLE II. INCORPORATION OF L-PHENYLALANINEG-14C AND L-TYROSINE-G-14C INTO LIGNINS OF BAMBOO STEMS

Dose, Specific activity

Species of Com- $\mu \mathrm{M} / \mathrm{g}$ of diketones from Dilution plant

wt. $\overbrace{\mathrm{VA}^{*}}^{\mathrm{SA}^{* *}}$

VA SA

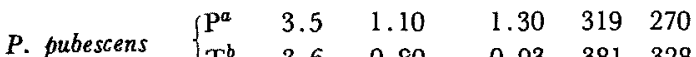

P. pubescens $\left\{\begin{array}{llllll}\mathrm{T}^{b} & 3.6 & 0.80 & 0.93 & 381 & 328\end{array}\right.$

$P$. reticulata $\left\{\begin{array}{llllll}\mathbf{P} & 3.5 & 1.25 & 1.21 & 280 & 290 \\ \mathrm{~T} & 3.6 & 0.95 & 1.16 & 321 & 263\end{array}\right.$

* VA; vanilloyl acetyl. ** SA; syringoyl acetyl.

a $\mathrm{P} ; \mathrm{L}$-phenylalanine-G.14 $\mathrm{C}(351 \mu \mathrm{C} / \mathrm{mM}), \quad b$ T; L-tyrosine$\mathrm{G}-{ }^{14} \mathrm{C}(305 \mu \mathrm{C} / \mathrm{mm})$. plants was quite good, and as expected the conversion of L-tyrosine to the diketones was about as good as L-phenylalanine as a precursor of bamboo lignin. ${ }^{17}$

Thus the results of present experiment conclusively show that phenylalanine deaminase and tyrase are both synthesized progressively in parallel with the lignification of bamboo and by the enzymes L-phenylalanine and Ltyrosine are deaminated to cinnamic acids and incorporated into lignin.

Acknowledgement. The technical assistance of Mr. K. Kojima is gratefully acknowledged.

17) S. A. Brown and A.C. Neish, Can. J. Biochem. Phy. siol., 34, 769 (1956). 